\title{
Short communication: Assessing urea transport from milk to blood in dairy cows
}

\author{
J. W. Spek, ${ }^{*}{ }^{1}$ J. Dijkstra, ${ }^{*}$ J. J. G. C. van den Borne, ${ }^{*}$ and A. Bannink $\dagger$ \\ *Animal Nutrition Group, Wageningen University, PO Box 338, $6700 \mathrm{AH}$, Wageningen, the Netherlands \\ †Wageningen UR Livestock Research, PO Box 65, 8200 AB, Lelystad, the Netherlands
}

\begin{abstract}
The concentration of urea in milk (MUC) has emerged as a potentially useful tool to predict urinary $\mathrm{N}$ excretion. Various factors may affect the relationship between MUC and urinary N excretion, including transport characteristics of urea from blood to milk and vice versa. The main objective of this study was to test whether substantial transport of urea from milk to blood exists in lactating dairy cattle. The subobjectives were (1) to assess the effects of various urea gradient levels between blood and milk on urea transport from milk to blood and (2) to test the occurrence of urea transport between different compartments of the mammary gland such as the cistern and the alveoli. Urea transport was studied in 2 multiparous lactating Holstein-Friesian cows $(36.0 \pm 6.18 \mathrm{~kg}$ of milk/d; mean $\pm \mathrm{SD})$. In 3 separate trials, boluses of $\left[{ }^{15} \mathrm{~N}^{15} \mathrm{~N}\right]$ urea were injected in the cisterns via the teat canals at 20,60, and $120 \mathrm{~min}$ before the 1700-h milking at various levels of MUC and of blood plasma urea concentration (PUC). In trial 1, a primed continuous infusion of urea (105 g at the start, continuing with $20 \mathrm{~g} / \mathrm{h}$ ) into the jugular vein started at $0500 \mathrm{~h}$ and stopped at $0,1,2$, and $3 \mathrm{~h}$ before the 1700-h milking on d $1,2,3$, and 4 , respectively. In trial $2,5.5 \mathrm{~g}$ of urea was injected into the cisterns at 20,60, and 120 min before the 1700-h milking on d 5, 6, and 7 , respectively. In trial 3 , urea fluxes were measured without an experimentally induced gradient between MUC and PUC on d 8, 9, and 10, respectively. During milking, successive milk samples were taken from first to last milk. Blood and milk were analyzed for ${ }^{15} \mathrm{~N}$-urea enrichment. Levels of ${ }^{15} \mathrm{~N}$-urea in blood increased after injection of a $\left[{ }^{15} \mathrm{~N}^{15} \mathrm{~N}\right]$ urea bolus in milk, indicating urea transport from milk to blood. Between 21.0 and $35.3 \%$ of injected $\left[{ }^{15} \mathrm{~N}^{15} \mathrm{~N}\right]$ urea in milk was recovered after $2 \mathrm{~h}$. The fractional $\left[{ }^{15} \mathrm{~N}^{15} \mathrm{~N}\right]$ urea decline rate in milk varied between 0.0076 and $0.0096 / \mathrm{min}$. The level of MUC, rather than the concentration gradient between MUC
\end{abstract}

Received January 31, 2012.

Accepted July 5, 2012.

${ }^{1}$ Corresponding author: wouter.spek@wur.nl and PUC, appeared to affect this fractional rate of decline. Enrichment levels of ${ }^{15} \mathrm{~N}$-urea in milk samples within a single milking showed that urea was transported from cistern milk to alveoli milk. In conclusion, the results indicate that transport of urea from milk to blood in lactating dairy cattle occurs and that urea is transported from cistern milk to alveoli milk.

Key words: milk urea, urea transport, mammary gland, dairy cattle

\section{Short Communication}

A positive relationship exists between the concentration of urea in milk (MUC; $\mathrm{mg} / \mathrm{dL}$ ) or in blood plasma (PUC; $\mathrm{mg} / \mathrm{dL}$ ) and excretion of $\mathrm{N}$ in urine (Ciszuk and Gebregziabher, 1994). Because of this positive relationship, MUC has been used to predict urinary $\mathrm{N}$ excretion and ammonia emission (Nousiainen et al., 2004; Burgos et al., 2007; van Duinkerken et al., 2011). However, the relationship is affected, among other factors, by diurnal dynamics in MUC, which in turn, is largely influenced by feed intake pattern (Gustafsson and Palmquist, 1993) and transport characteristics of urea from blood to milk and vice versa.

Although it is well known that urea is transported from blood to milk, the reverse transfer of milk urea to blood is hardly investigated. Quantitative knowledge on urea diffusion from milk to blood may help in understanding the dynamics of MUC in dairy cows and its effect on the relationship between MUC and N excretion in urine. Linzell and Peaker (1971) reported that in 2 goats, 82 and $70 \%$ of injected ${ }^{14} \mathrm{C}$-urea in milk via the teat canals was recovered in the milk at $1 \mathrm{~h}$ after injection. For high-yielding dairy cows with a much higher milk yield and a mammary gland structure that differs (e.g., the ratio of cistern milk to alveoli milk) from that in goats, urea disappearance from milk in the mammary gland has not been assessed. In their experiment, Linzell and Peaker (1971) also estimated the diffusion of lactose between different compartments in the mammary gland by injecting labeled lactose in the teat pouch and by collection of milk portions from cistern milk to alveoli milk. The quantity of injected 
labeled lactose recovered in residual milk after oxytocin injection was 7 and 14\% 10 and 20 min after injection, respectively. These observations suggest that the occurrence of internal diffusion of lactose in the mammary gland and, similarly, intramammary urea diffusion may occur as well. This route of diffusion of urea is of interest because it may affect urea transport between milk and blood and, consequently, the relationship between MUC and urinary N excretion.

The main objective of the current study was to test whether substantial transport of urea from milk to blood exists in lactating dairy cattle. The subobjectives were (1) to assess the effects of various urea gradient levels between blood and milk on urea transport from milk to blood in lactating dairy cattle and (2) to test the occurrence of urea transport between different compartments of the mammary gland such as the cistern and the alveoli.

The study was approved by the Institutional Animal Care and Use Committee of the Animal Sciences Group at Wageningen University and Research Centre (Lelystad, the Netherlands). Three trials were conducted with 2 tethered, multiparous lactating Holstein-Friesian cows $(36.0 \pm 6.18 \mathrm{~kg}$ of milk $/ \mathrm{d}, 595 \pm 37.3 \mathrm{~kg}$ of BW, and $66 \pm 8.5$ DIM; means \pm SD) fed a TMR based on maize silage with $155 \mathrm{~g}$ of CP per kilogram of DM. To prevent variation in DMI (and, consequently, variation in PUC and MUC) between days, cows were fed at $90 \%$ of their ad libitum intake, which was determined during a period of 2 wk before the start of the measurement period. On measurement days, feed was offered in equal portions every $2 \mathrm{~h}$ during the daytime $(0500-1700 \mathrm{~h})$ to minimize fluctuations in PUC and MUC, whereas on other days, cows were fed equal portions at 0500 and $1700 \mathrm{~h}$. Cows were milked twice daily at 0500 and $1700 \mathrm{~h}$. Three days before the first measurement day, a double lumen semipermanent catheter was inserted in the left jugular vein of the cows for collection of blood samples and infusion of urea.

In trial 1, we tried to establish a positive gradient between MUC and PUC. A primed continuous infusion of urea $(105 \mathrm{~g}$ at the start, continuing with $20 \mathrm{~g} / \mathrm{h}$ ) into the jugular vein started at $0500 \mathrm{~h}$ and stopped at $0,1,2$, and $3 \mathrm{~h}$ before the 1700-h milking on $\mathrm{d} 1,2,3$, and 4, respectively. Two hours before milking, $50 \mathrm{mg}$ of $\left[{ }^{15} \mathrm{~N}^{15} \mathrm{~N}\right]$ urea $\left(98 \%{ }^{15} \mathrm{~N}\right.$ enriched; Sigma-Aldrich, Zwijndrecht, the Netherlands) dissolved in $40 \mathrm{~mL}$ of saline was injected in the cisterns of the mammary gland via the teat canals (i.e., $10 \mathrm{~mL}$ per cistern).

In trial 2, a positive gradient between MUC and PUC was established by direct injection of $5.5 \mathrm{~g}$ of urea dissolved in $40 \mathrm{~mL}$ of saline into the cisterns via the teat canals (i.e., $10 \mathrm{~mL}$ per cistern) at 20,60, and $120 \mathrm{~min}$ before the 1700-h milking on d 5,6, and 7, respectively.
In addition, $70 \mathrm{mg}$ of $\left[{ }^{15} \mathrm{~N}^{15} \mathrm{~N}\right]$ urea was simultaneously injected into the mammary gland cistern (i.e., $17.5 \mathrm{mg}$ per cistern).

In trial 3, urea fluxes were measured without an experimentally induced gradient between MUC and PUC. Twenty milligrams of $\left[{ }^{15} \mathrm{~N}^{15} \mathrm{~N}\right]$ urea dissolved in $40 \mathrm{~mL}$ saline was injected into the cisterns (i.e., 10 $\mathrm{mL}$ per cistern) of the mammary gland at 20,60 , and 120 min before the 1700 -h milking on $\mathrm{d} 8,9$, and 10 , respectively.

Related to subobjective 2 , milk was collected in trials 2 and 3 in portions of approximately $2 \mathrm{~L}$ using a WB HI/Pullout Tru-Test device (Tru-Test Ltd., Auckland, New Zealand) at the 1700-h milking and each portion was sampled. Directly after milking, 20 IU of oxytocin was injected intravenously, after which the residual milk was collected and sampled as well. In addition, a representative sample of the total collected milk was composed. Blood samples were taken in hourly intervals, starting at $3 \mathrm{~h}$ before milking until milking. Samples of milk and blood plasma were stored at $-20^{\circ} \mathrm{C}$ pending analysis.

Milk and blood samples were analyzed for urea concentration and for ${ }^{15} \mathrm{~N}$ enrichment in urea. Milk samples were defatted by removing the fat after centrifugation at $9,000 \times g$ for $15 \mathrm{~min}$ at room temperature and the defatted solution was deproteinized by centrifugation at $10,600 \times g$ for $15 \mathrm{~min}$ at $4^{\circ} \mathrm{C}$ after precipitation of milk protein with TCA (10\%). The resulting fat- and protein-free solution was used for analysis of urea concentration and ${ }^{15} \mathrm{~N}$ enrichment in urea. Blood plasma samples were deproteinized by centrifugation at 10,600 $\times g$ for 15 min at $4^{\circ} \mathrm{C}$ after precipitation of plasma protein with TCA (10\%). Urea concentration in blood plasma and milk was analyzed with the urea liquicolor test no. 10505 (HUMAN GmbH, Wiesbaden, Germany), which is based on measuring absorbance (578 nm) after a modified Berthelot reaction. Urea in the fat- and protein-free solution samples of milk was isolated by cation-exchange chromatography (Dowex 50WX8-400 cation-exchange resin, protonated with $0.1 \mathrm{M} \mathrm{HCl}$ solution; Sigma-Aldrich) and elution with water. The first $4 \mathrm{~mL}$ of the eluent, containing lactose, was discarded, whereas the following $30 \mathrm{~mL}$ of the eluent, containing the majority of milk urea (>95\%) was collected. This $30 \mathrm{~mL}$ of eluent was dried with a rotary evaporator at $60^{\circ} \mathrm{C}$, redissolved in $1 \mathrm{~mL}$ of water, transferred into capsules of tin, and analyzed for total ${ }^{15} \mathrm{~N}$ enrichment using an elemental analyzer-isotopic ratio mass spectrometer system (EA-IRMS; EA model DP 200 series 2, Finnigan, Milan, Italy; IRMS model DELTA S, Thermo Finnigan, Milan Italy). It was assumed that the ${ }^{15} \mathrm{~N}$ enrichment in milk urea was entirely caused by the quantity of $\left[{ }^{15} \mathrm{~N}^{15} \mathrm{~N}\right]$ urea infused, whereas the 
quantity of infused $\left[{ }^{15} \mathrm{~N}^{15} \mathrm{~N}\right]$ urea that is transported to the blood and returned to the milk was assumed to be negligible due to the strong dilution of ${ }^{15} \mathrm{~N}$ urea in the total plasma pool.

Data were analyzed with the PROC GLM procedure of SAS (SAS Institute Inc., Cary, NC) in which cow and trial were added as class variables whenever data from cows or trials were pooled, whereas all other factors such as PUC, MUC, ${ }^{15} \mathrm{~N}$-urea enrichment percentage in milk, and time were added as fixed continuous variables. In trial 2 and 3 , the recovered ${ }^{15} \mathrm{~N}$-urea in milk was used to estimate the fractional disappearance rate of injected $\left[{ }^{15} \mathrm{~N}^{15} \mathrm{~N}\right]$ urea according to an exponential model with the NLIN procedure of SAS.

In trial 1 , between 24.9 and $35.3 \%$ of $\left[{ }^{15} \mathrm{~N}^{15} \mathrm{~N}\right]$ urea injected in the cisterns of the mammary gland at 2 $\mathrm{h}$ before milking was recovered in the milk (Table 1 ). This indicates urea transfer from the mammary gland into other body fluids such as blood plasma. The recovery of ${ }^{15} \mathrm{~N}$-urea in milk was highest $(35.3 \%)$ for the treatment in which intravenous urea infusion continued until milking, and lowest (24.9\%) when infusion of urea was stopped at $3 \mathrm{~h}$ before milking, but these differences were not significant $(P=0.22)$, possibly due to the small number of animals in this experiment. The results of trial 1 indicate a positive relationship between recovery of ${ }^{15} \mathrm{~N}$-urea in milk and the level of MUC $\left(\mathrm{R}^{2}=0.73, P=0.02\right)$. Recovery of ${ }^{15} \mathrm{~N}$-urea in milk was not related to the urea concentration gradient between plasma and milk urea $\left(\mathrm{R}^{2}=0.10, P=0.82\right)$. Standard deviations of PUC and MUC in trial 1 (Table 1) varied between 0.59 and $3.22 \mathrm{mg} / \mathrm{dL}$ for MUC and between 2.78 and $6.59 \mathrm{mg} / \mathrm{dL}$ for PUC. Reasons for this range in standard deviations might, among others, result from differences in water intake between cows, as some indications exist that water intake affects MUC (Burgos et al., 2001; J. W. Spek, unpublished data). However, water intake was not measured in this study.

Trials 2 and 3 confirmed the transfer of urea from the mammary gland into plasma observed in trial 1 .
Between 21.0 and $34.3 \%$ of the labeled urea injected into the mammary gland was recovered in milk at $2 \mathrm{~h}$ after injection in trials 2 and 3 (Figure 1). The average MUC (mean \pm SD) was substantially higher in trial 2 $(43.3 \pm 5.49)$ than in trial $3(20.1 \pm 2.33)$, which was a consequence of injecting a bulk of unlabeled urea next to injection of the labeled urea in the cisterns in trial 2 . The average PUC (mean $\pm \mathrm{SD}$ ) was similar in trial $2(23.3 \pm 2.37)$ and trial $3(22.8 \pm 3.93)$, resulting in a larger gradient between PUC and MUC in trial 2.

In line with results from trial 1 , results from trials 2 and 3 indicate that more ${ }^{15} \mathrm{~N}$ urea was recovered in milk with a higher MUC and independent of the gradient between MUC and PUC. With lower MUC (trial 3 vs. trial 2), the percentage of ${ }^{15} \mathrm{~N}$-urea recovered in milk after 60 and 120 min was reduced $(-18 \%, P=0.02)$, whereas the concentration gradient between PUC and MUC had no effect on fractional urea transport from milk to blood $\left(\mathrm{R}^{2}=0.07, P=0.56\right)$. These results indicate a negative association between MUC and fractional urea transport from milk to blood. The rise in ${ }^{15} \mathrm{~N}$ enrichment of plasma urea after $\left[{ }^{15} \mathrm{~N}^{15} \mathrm{~N}\right]$ urea injection in the mammary gland in trial 3 (Figure 2) indicates that transport of urea from mammary gland to blood occurred. For d $9,55 \%$ of the injected $\left[{ }^{15} \mathrm{~N}^{15} \mathrm{~N}\right]$ urea was recovered in the milk. Based on (1) the increase in ${ }^{15} \mathrm{~N}$ enrichment of urea in blood plasma, (2) level of PUC, and (3) an assumed urea distribution volume of $68 \%$ of BW as found by Agnew et al. (2005), around 29\% of the injected $\left[{ }^{15} \mathrm{~N}^{15} \mathrm{~N}\right]$ urea in the mammary gland was recovered in blood plasma. The exponential disappearance curves of ${ }^{15} \mathrm{~N}$-urea in milk (Figure 1) show intercept values of $83.5 \%$, indicating an unaccountable loss of injected $\left[{ }^{15} \mathrm{~N}^{15} \mathrm{~N}\right]$ urea in the order of magnitude of $16 \%$ as well. The loss of injected labeled urea may be due to an immediate distribution within the mammary gland urea space volume, which is larger than the milk volume, or some conversion of absorbed urea into ammonia upon transport into the gastrointestinal tract. Given the very low amounts of ammonia in milk,

Table 1. Trial 1: effect of the time interval between ending an intravenous urea infusion and milking on urea concentrations in the milk and the blood, on the urea concentration gradient between plasma and milk urea, and on the 2-h recovery of an intramammary bolus injection of $\left[{ }^{15} \mathrm{~N}^{15} \mathrm{~N}\right]$ urea in milk $(\mathrm{n}=2$; data presented as means $\pm \mathrm{SD})$

\begin{tabular}{|c|c|c|c|c|}
\hline $\begin{array}{l}\text { Time between the end of urea } \\
\text { infusion and milking }(\mathrm{h})\end{array}$ & $\operatorname{MUC}^{1}(\mathrm{mg} / \mathrm{dL})$ & $\mathrm{PUC}^{2}(\mathrm{mg} / \mathrm{dL})$ & $\begin{array}{l}\text { Urea concentration } \\
\text { gradient }(\mathrm{mg} / \mathrm{dL})\end{array}$ & $\begin{array}{l}{ }^{15} \mathrm{~N} \text {-urea recovered } \\
\text { in milk }{ }^{3}(\%)\end{array}$ \\
\hline 0 & $69.7 \pm 3.22$ & $77.1 \pm 3.56$ & $7.4 \pm 6.78$ & $35.3 \pm 1.96$ \\
\hline 1 & $58.1 \pm 0.59$ & $60.2 \pm 6.59$ & $2.1 \pm 7.18$ & $27.3 \pm 1.23$ \\
\hline 3 & $53.6 \pm 1.84$ & $51.4 \pm 2.79$ & $-2.1 \pm 0.59$ & $24.9 \pm 7.63$ \\
\hline
\end{tabular}

${ }^{1}$ Milk urea concentration.

${ }^{2}$ Blood plasma urea concentration. Values of PUC are averages of 2 PUC values, one value of PUC at $1 \mathrm{~h}$ before milking and a second value of PUC at the moment of milking.

${ }^{3}$ The percentage of an intramammary bolus of $\left[{ }^{15} \mathrm{~N}^{15} \mathrm{~N}\right]$ urea at $2 \mathrm{~h}$ before milking that is recovered in milk. 


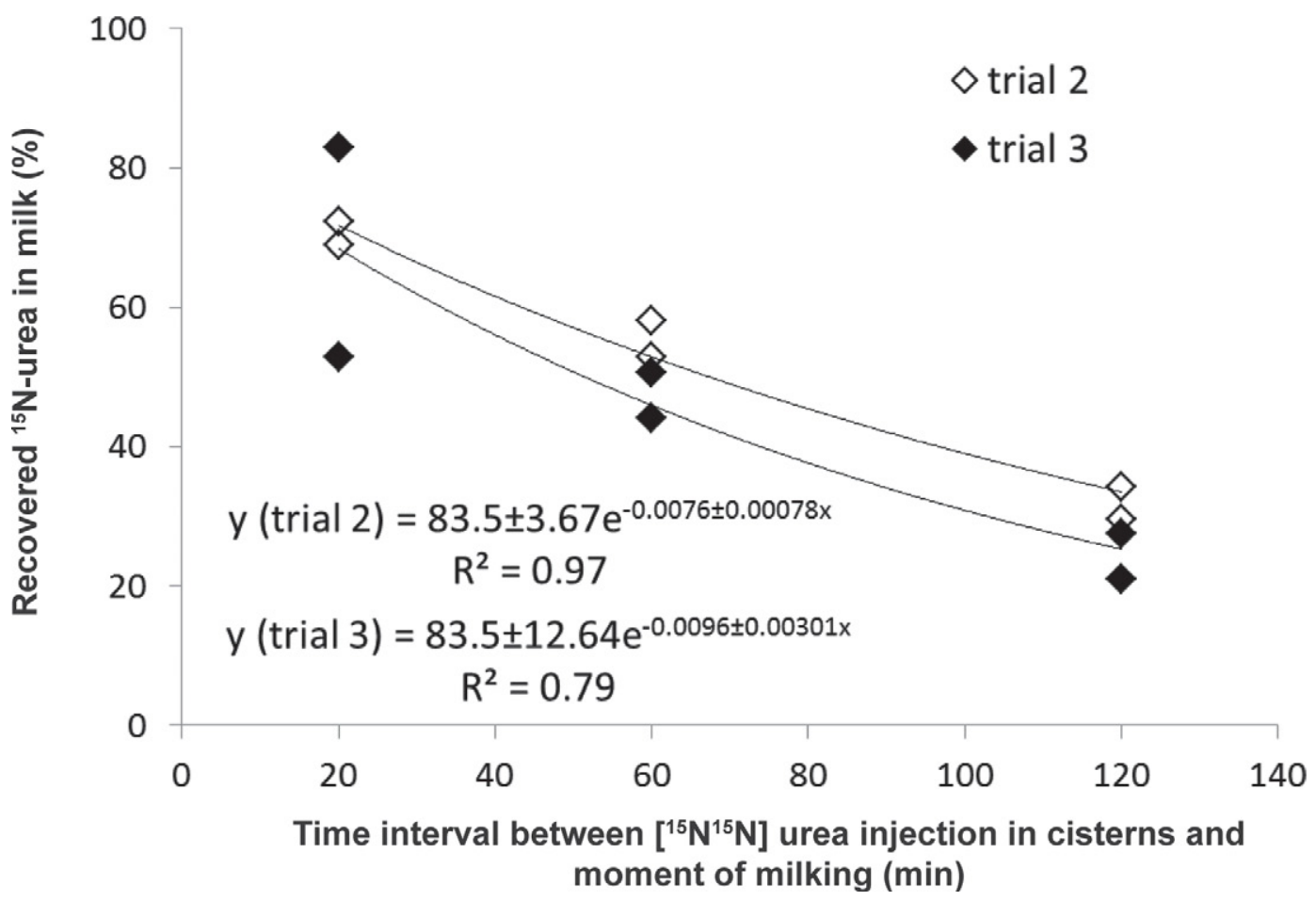

Figure 1. Effect of time interval $(20,60$, or $120 \mathrm{~min})$ between $\left[{ }^{15} \mathrm{~N}^{15} \mathrm{~N}\right]$ urea injection into the cisterns and milking on recovered ${ }^{15} \mathrm{~N}$-urea in milk (\% of injected) in trials 2 and 3. In trial $2,70 \mathrm{mg}$ of $\left.{ }^{15} \mathrm{~N}^{15} \mathrm{~N}\right]$ urea and $5.5 \mathrm{~g}$ of unlabeled urea were injected into the cistern of the mammary gland via the teat canals at 20,60, and 120 min before milking at $1700 \mathrm{~h}$, whereas in trial $3,20 \mathrm{mg}$ of $\left[{ }^{15} \mathrm{~N}^{15} \mathrm{~N}\right]$ urea (no unlabeled urea) was injected into the cistern of the mammary gland at 20,60, and 120 min before milking at $1700 \mathrm{~h}$.

significant conversion of urea by urease activity in milk is unlikely.

In Figure 3, the ${ }^{15} \mathrm{~N}$-urea enrichment in the milk fractions from first (cistern) to last (alveoli) milk are plotted for each of the 3 moments before milking (20, 60 , and $120 \mathrm{~min}$ ) when a bolus of $\left[{ }^{15} \mathrm{~N}^{15} \mathrm{~N}\right]$ urea was injected into the cisterns of the mammary gland. Table 2 presents the parameter estimates of third-order poly-

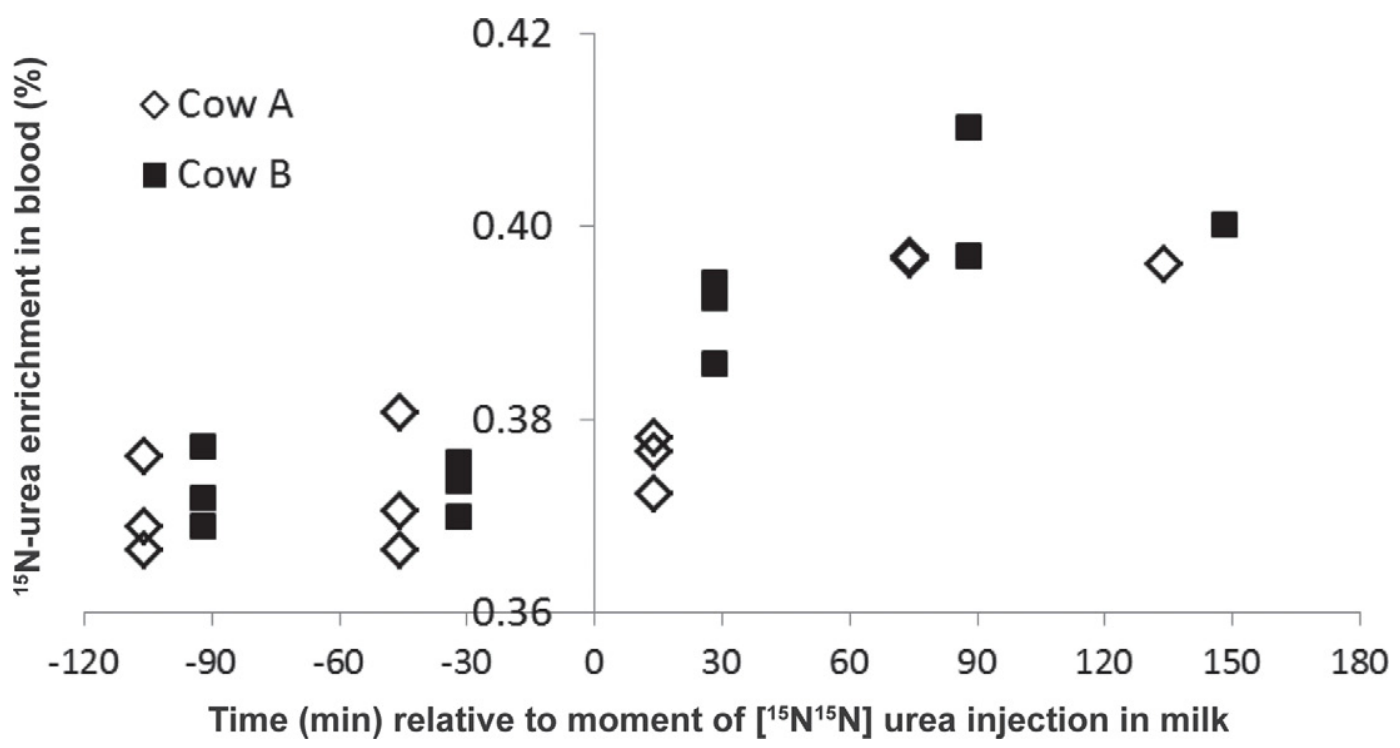

Figure 2. ${ }^{15} \mathrm{~N}$-urea enrichment in blood before and after injection of $\left[{ }^{15} \mathrm{~N}^{15} \mathrm{~N}\right]$ urea in milk in trial 3. 

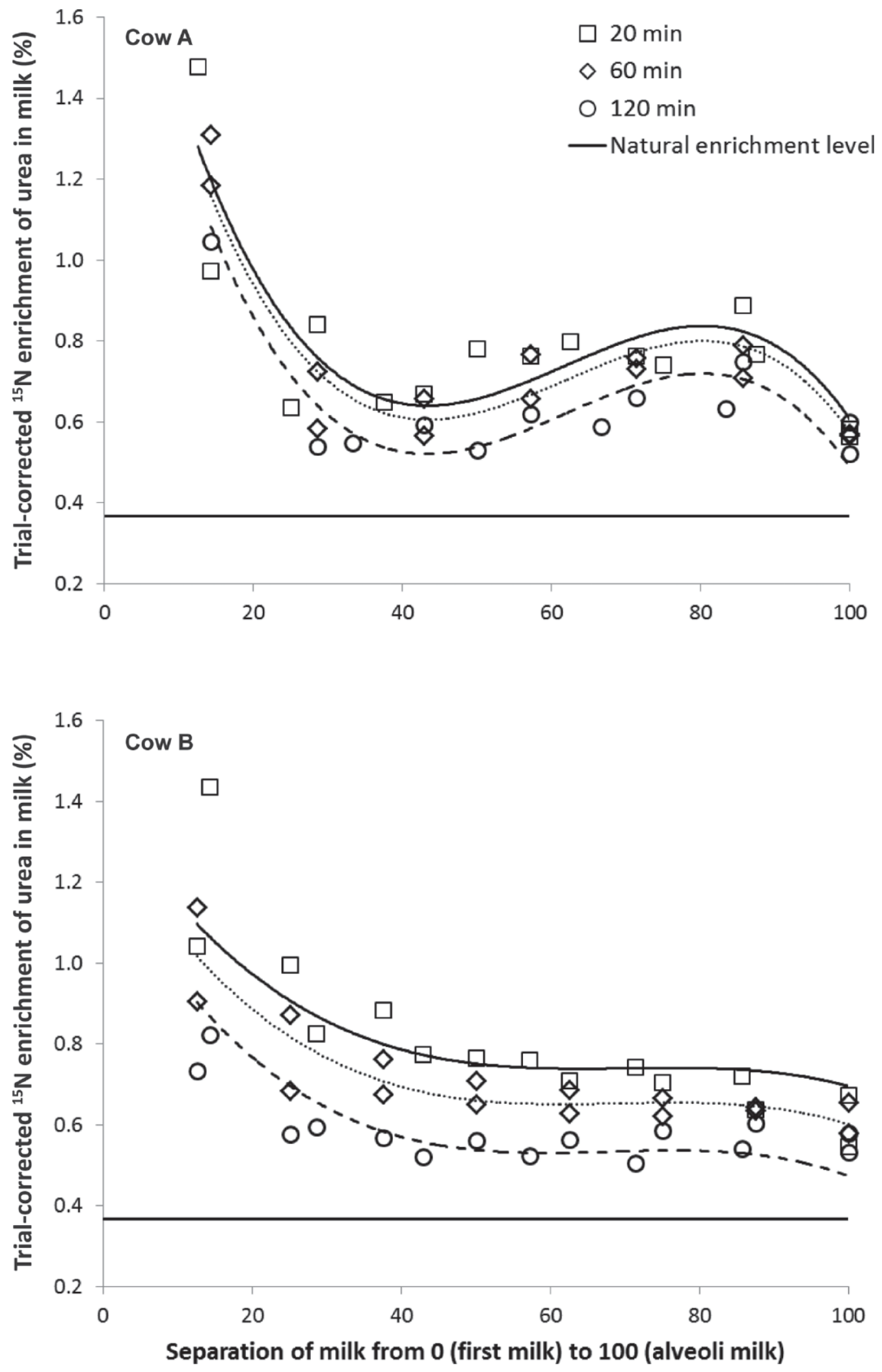

Figure 3. Trial-corrected enrichment of ${ }^{15} \mathrm{~N}$-urea in milk from the first (cistern) to the last milk (alveoli) based on data from trials 2 and 3 and presented individually for cow A and B. ${ }^{15} \mathrm{~N}^{15} \mathrm{~N}$ ) urea was injected in the cisterns at 20, 60, and 120 min before milking on 3 consecutive days. Third-order polynomial models were fitted to the data (estimates presented in Table 2) resulting in $\mathrm{R}^{2}$ values of 0.84 and 0.85 for cow $\mathrm{A}$ and $\mathrm{B}$, respectively. Solid line $=20 \mathrm{~min}$, dotted line $=60 \mathrm{~min}$, and the dashed line $=120 \mathrm{~min}$. 
Table 2. Model parameters of regression of a third-order polynomial model of ${ }^{15} \mathrm{~N}$ enrichment distribution in milk from first to last milk in cows A and B separately, based on observations from trials 2 and 3 (regression results shown in Figure 2)

\begin{tabular}{|c|c|c|c|c|c|c|}
\hline \multirow[b]{2}{*}{ Parameter $^{1}$} & \multicolumn{3}{|c|}{ Cow A } & \multicolumn{3}{|c|}{ Cow B } \\
\hline & Estimate & SE & $P$-value & Estimate & $\mathrm{SE}$ & $P$-value \\
\hline Intercept & 1.89 & 0.116 & $<0.001$ & 1.07 & 0.098 & $<0.001$ \\
\hline Trial 2 & 0.13 & 0.029 & $<0.001$ & 0.254 & 0.0267 & $<0.001$ \\
\hline Trial 3 & 0 & & & & & \\
\hline $20 \mathrm{~min}$ & 0.119 & 0.0358 & 0.002 & 0.226 & 0.0331 & $<0.001$ \\
\hline $60 \mathrm{~min}$ & 0.0876 & 0.03634 & 0.022 & 0.1294 & 0.03252 & $<0.001$ \\
\hline $120 \mathrm{~min}$ & 0 & & & 0 & & \\
\hline $\mathrm{X}$ & -0.0808 & 0.00777 & $<0.001$ & -0.0301 & 0.00686 & $<0.001$ \\
\hline $\mathrm{X}^{\wedge 2}$ & 0.00143 & 0.000152 & $<0.001$ & 0.00044 & 0.000137 & 0.003 \\
\hline $\mathrm{X}^{\wedge 3}$ & $-7.73 \mathrm{E}-6$ & $0.88 \mathrm{E}-6$ & $<0.001$ & $-2.13 \mathrm{E}-6$ & $0.80 \mathrm{E}-06$ & 0.011 \\
\hline
\end{tabular}

${ }^{1}$ The parameter $\mathrm{X}$ can vary from 0 (first milk) to 100 (last milk) and it indicates a subcompartment of milk in the mammary gland, ranging from the cistern (first milk) to the alveoli (last milk).

nomial models fitted with the PROC GLM procedure of SAS for cow A and B in Figure 2. The results presented in Figure 2 indicate that injected $\left[{ }^{15} \mathrm{~N}^{15} \mathrm{~N}\right]$ urea in the cisterns of the cow diffuses toward the alveoli. Especially for cow A, the ${ }^{15} \mathrm{~N}$-urea enrichment curve suggests that urea transport in milk cannot simply be explained by a single-compartment model, as indicated by the best fit obtained with a third-order polynomial model represented in Table 2. Compared with cow B, an increase in ${ }^{15} \mathrm{~N}$-urea enrichment in the second half of the milk obtained during a milking in cow A was observed (Figure 3). These differences between cow A and $\mathrm{B}$ may indicate physiological differences in mammary gland morphology such as blood circulation, degree of urea diffusion between blood and milk of the various mammary gland compartments, or milk release characteristics from the different quarters of the udder (or a combination of these).

In conclusion, our results indicate that transport of urea from milk to blood in lactating dairy cattle occurs and that this transport is related to MUC level. Moreover, results indicate that urea is transported intramammarily from cistern to alveoli milk.

\section{REFERENCES}

Agnew, R. E., T. Yan, W. J. McCaughey, J. D. McEvoy, D. C. Patterson, M. G. Porter, and R. W. J. Steen. 2005. Relationships between urea dilution measurements and body weight and composition of lactating dairy cows. J. Dairy Sci. 88:2476-2486.

Burgos, M. S., M. Senn, F. Sutter, M. Kreuzer, and W. Langhans. 2001. Effect of water restriction on feeding and metabolism in dairy cows. Am. J. Physiol. Regul. Integr. Comp. Physiol. 280:R418-R427.

Burgos, S. A., J. G. Fadel, and E. J. DePeters. 2007. Prediction of ammonia emission from dairy cattle manure based on milk urea nitrogen: Relation of milk urea nitrogen to urine urea nitrogen excretion. J. Dairy Sci. 90:5499-5508.

Ciszuk, P., and T. Gebregziabher. 1994. Milk urea as an estimate of urine nitrogen of dairy cows and goats. Acta Agric. Scand. A Anim. Sci. 44:87-95.

Gustafsson, A. H., and D. L. Palmquist. 1993. Diurnal variation of rumen ammonia, serum urea, and milk urea in dairy cows at high and low yields. J. Dairy Sci. 76:475-484.

Linzell, J. L., and M. Peaker. 1971. The permeability of mammary ducts. J. Physiol. 216:701-716.

Nousiainen, J., K. J. Shingfield, and P. Huhtanen. 2004. Evaluation of milk urea nitrogen as a diagnostic of protein feeding. J. Dairy Sci. $87: 386-398$.

van Duinkerken, G., M. C. J. Smits, G. André, L. B. J. Šebek, and J. Dijkstra. 2011. Milk urea concentration as an indicator of ammonia emission from dairy cow barn under restricted grazing. J. Dairy Sci. 94:321-335. 